\title{
Analisis Kinerja dan Strategi Perdagangan Indonesia-MERCOSURE
}

\author{
Hastuti $^{1}$, Wibowo ${ }^{2}$, Anda Nugroho ${ }^{3}$, Dea Amanda ${ }^{4}$ \\ ${ }^{1,4}$ Departemen Ekonomi Sumberdaya dan Lingkungan, Fakultas Ekonomi dan Manajemen, Institut \\ Pertanian Bogor, Jalan Agatis, Kampus Darmaga, Bogor 16680, Indonesia \\ ${ }^{2}$ Pusat Pengkajian Kerjasama Perdagangan Internasional, Badan Pengkajian dan Pengembangan \\ Perdagangan, Kementerian Perdagangan, Republik Indonesia \\ ${ }^{3}$ Bea Cukai, Kementerian Keuangan, Republik Indonesia \\ *Korespondensi: hastuti_esl@apps.ipb.ac.id
}

[diterima: Maret 2019- revisi: Juli 2019- diterbitkan daring: Desember 2019]

\begin{abstract}
ABSTRAK
Indonesia telah menjalin berbagai hubungan kerjasama dengan negara-negara Amerika Latin. Berbagai upaya penjajakan kerjasama terus dilakukan, diantaranya dengan MERCOSUR (terdiri dari Brazil, Argentina, Paraguay, dan Uruguay). Negara-negara anggota MERCOSUR merupakan pasar potensial untuk produk ekspor Indonesia. Tujuan penelitian ini: (1) mengidentifikasi kinerja perdagangan Indonesia-MERCOSUR, (2) menganalisis faktor-faktor yang memengaruhi ekspor Indonesia ke MERCOSUR, dan (3) merumuskan strategi kerjasama perdagangan IndonesiaMERCOSUR. Metode analisis yang digunakan adalah: Analisis deskriptif kualitatif, Gravity Model dan Analisis SWOT. Kinerja perdagangan Indonesia- MERCOSUR, menunjukkan nilai ekspor impor Indonesia dengan MERCOSUR masih kecil dibandingkan dengan negara-negara pesaing. Tarif impor yang diberlakukan oleh negara-negara MERCOSUR terhadap produk-produk utama Indonesia masih relatif tinggi, sebaliknya tarif impor yang diberlakukan oleh Indonesia terhadap produk-produk utama MERCOSUR relatif rendah. Hasil estimasi Gravity Model menunjukkan ekspor Indonesia ke MERCOSUR dipengaruhi secara positif dan hanya signifikan oleh GDP negara-negara MERCOSUR. Rekomendasi strategi kerjasama perdagangan yang dihasilkan yaitu: (a) mengoptimalkan kemampuan Indonesia memenuhi pasar MERCOSUR terutama pada produk seperti: kelapa sawit, karet, onderdil kendaraan bermotor, serat buatan, alas kaki, kelapa dan tembakau, (b) meningkatkan kerjasama secara intensif kepada negara-negara MERCOSUR dalam bentuk Free Trade Area (FTA), (c) memperbaiki stuktur tarif dan hambatan non tarif antara Indonesia- MERCOSUR. dan (d) meningkatkan diplomasi ekonomi Indonesia-MERCOSUR.
\end{abstract}

Kata Kunci: Analisis SWOT, Argentina, Brazil, Gravity Model, Paraguay, Uruguay

\begin{abstract}
Indonesia has established various cooperative relationships with Latin American countries. Various efforts to explore Indonesia's cooperation with other countries has been continuously done, especially with MERCOSUR founding countries (Brazil, Argentina, Paraguay, and Uruguay) as potential market for Indonesian export products. The objectives of this study are: (1) identifying the trade performance between Indonesia and MERCOSUR countries; (2) analyzing factors affecting Indonesia's export to MERCOSUR countries; and (3) formulating strategies for trade cooperation between Indonesia and MERCOSUR countries. The analytical methods used are: Qualitative Descriptive Analysis, Gravity Model and SWOT Analysis. The results shows that the value of Indonesia's exports and imports to MERCOSUR countries is still small compared to other competing countries. Import tariffs imposed by MERCOSUR countries on Indonesia's main export products are still relatively high, on the contrary
\end{abstract}


import tariffs imposed by Indonesia on MERCOSUR's main products are relatively low. Indonesia's exports to MERCOSUR countries are positively and significantly affected by the GDP of MERCOSUR countries. The recommendations for Indonesia-MERCOSUR trade cooperation strategies are: (1) optimizing Indonesia's ability to meet the MERCOSUR market, especially for palm oil, rubber, auto parts, artificial fibers, footwear, coconuts and tobacco; (2) increasing cooperation intensity in Free Trade Area (FTA) form; (3) improving tariff structure and non-tariff barriers; and (4) strengthening the economic diplomacy.

Keywords: SWOT Analysis, Argentina, Brazil, Gravity Model, Paraguay, Uruguay JEL Classification: F1, F5, F13

\section{PENDAHULUAN}

\section{Latar Belakang}

Perdagangan internasional berperan penting dalam perekonomian dunia. Terbukanya suatu negara terhadap perdagangan internasional membuat peluang ekspor komoditas dari suatu negara ke negara lain semakin tinggi, sehingga dapat meningkatkan pendapatan negara tersebut (Amalina, 2018). Sejak tahun 2017, Indonesia menjalin hubungan perdagangan internasional melalui berbagai kerjasama dengan negaranegara Amerika Latin. Bentuk hubungan kerjasama tersebut dapat dilihat pada perundingan antara Indonesia dengan Chile dan juga Peru. Selain upaya perluasan pasar pada ksuatu kawasan melalui pengembangan hubungan bilateral, pengembangan hubungan perdagangan juga dapat dilakukan melalui pendekatan dengan blok perdagangan regional pada kawasan tersebut. Blok perdagangan yang ada di kawasan Amerika Latin adalah MERCOSUR, yang terdiri dari Brazil, Argentina, Paraguay, dan Uruguay.

Negara-negara anggota MERCOSUR merupakan negara potensial untuk pasar ekspor Indonesia. Pada Tabel 1 terlihat bahwa dengan jumlah populasi negara anggota MERCOSUR yang mencapai 263.45 juta pada tahun 2018 serta tingkat pendapatan per kapita yang lebih tinggi dibandingkan Indonesia, negara-negara MERCOSUR merupakan pasar potensial bagi produk ekspor Indonesia. Data perbandingan kondisi indikator makroekonomi lain antara Indonesia dengan negara-negara MERCOSUR dapat dilihat pada Tabel 1.

Tabel 1. Perbandingan Indikator Makroekonomi antara Indonesia-MERCOSUR Tahun 2018

\begin{tabular}{lllrrrrr}
\hline \multicolumn{1}{c}{ Indikator } & \multicolumn{1}{c}{ Unit } & Skala & Argentina & Brazil & Paraguay & Uruguay & Indonesia \\
\hline GDP current prices & U.S. dollars & Billions & 518.09 & 1868.18 & 41.6 & 60.18 & 1022.45 \\
GDP per capita & U.S. dollars & Units & 11626.92 & 8967.66 & 5898.81 & 17164.89 & 3870.56 \\
Inflation (acp) & Percent change & & 34.3 & 3.67 & 4 & 7.6 & 3.2 \\
Unemployment rate & Percent of total & & 9.2 & 12.3 & 5.6 & 8.05 & 5.3 \\
Populasi & labor force & \multirow{2}{*}{ Millions } & 44.56 & 208.33 & 7.05 & 3.51 & 264.16 \\
\hline
\end{tabular}

Tingkat pengangguran di negara-negara MERCOSUR juga lebih besar yaitu antara 5.60\% (Paraguay) hingga 12.30\% (Brazil) dibandingkan dengan Indonesia yang hanya sebesar $5.30 \%$ Jumlah penduduk Indonesia yang tinggi dan tingkat pengangguran yang lebih rendah di bandingan dengan MERCOSUR menjadi salah satu potensi perdagangan bagi Indonesia. Jumlah penduduk menjadi sumber tenaga kerja dalam meningkatkan pertumbuhan ekonomi. Menurut Salvatore (1997) banyaknya tenaga kerja sangat membantu dalam proses menghasilkan barang untuk kegiatan ekspor. Teori kemanfaatan absolut (absolut advantage) oleh Adam Smith 
menjelaskan nilai suatu barang diukur dengan banyaknya tenaga kerja yang digunakan untuk menghasilkan barang. Makin banyak tenaga kerja yang digunakan akan makin tinggi nilai barang tersebut (labor theory of value).

Tingkat inflasi negara-negara MERCOSUR relatif lebih tinggi dibandingkan dengan Indonesia, kecuali Brazil dimana tingkat inflasi Indonesia sama dengan Brazil yaitu sebesar $3.67 \%$ pada tahun 2018. Tingkat inflasi Agrentina merupakan yang tertinggi bahkan mencapai $34.30 \%$ pada tahun 2018. Gambaran inflasi tersebut menunjukkan lonjakan harga secara agregat di MERCOSUR cenderung lebih rentan dibandingkan dengan Indonesia. Kenaikan harga ini menjadi pendorong bagi produsen dan eksportir untuk meningkatkan produksi dan ekspornya.

Berdasarkan data ITC (2019), total perdagangan Indonesia ke MERCOSUR pada periode 2014-2018 didominasi oleh non migas yang mengalami penurunan rata-rata sebesar $5 \%$ per tahun. Meskipun demikian, total perdagangan Indonesia ke MERCOSUR pada tahun 2018 mengalami peningkatan dari tahun sebelumnya yaitu dari USD 4,71 milyar menjadi sebesar USD 4.79 milyar. Hal ini menunjukkan bahwa perdagangan Indonesia dengan negara-negara MERCOSUR masih dapat terus ditingkatkan. Total Perdagangan Indonesia dengan negaranegara MERCOSUR dapat dilihat pada Tabel 2.

Tabel 2. Neraca Perdagangan Indonesia - MERCOSUR Periode 2014-2018

\begin{tabular}{|c|c|c|c|c|c|c|c|c|c|}
\hline \multirow{3}{*}{ Uraian } & \multicolumn{7}{|c|}{ Dalam Nilai: USD Juta } & \multirow{3}{*}{$\begin{array}{c}\begin{array}{c}\text { Perub } \\
(\%)\end{array} \\
19 / 18\end{array}$} & \multirow{3}{*}{$\begin{array}{c}\begin{array}{c}\text { Trend } \\
(\%)\end{array} \\
14-18\end{array}$} \\
\hline & \multirow{2}{*}{2014} & \multirow{2}{*}{2015} & \multirow{2}{*}{2016} & \multirow{2}{*}{2017} & \multirow{2}{*}{2018} & \multicolumn{2}{|c|}{ Jan-Feb } & & \\
\hline & & & & & & 2018 & 2019 & & \\
\hline $\begin{array}{l}\text { Total } \\
\text { Pordagangan }\end{array}$ & 5909.9 & 5205.3 & 5234.5 & 4712.1 & 4799.4 & 777.1 & 882.3 & 13.5 & (5.0) \\
\hline 1. Mig & 4.7 & 0.1 & 4.1 & 0.2 & 9.8 & 0.0 & 6.2 & 0.0 & 27.8 \\
\hline 2. Non Migas & 5905.2 & 5205.2 & 5230.4 & 4711.8 & 4789.5 & 777.1 & 876.1 & 12.7 & (5.1) \\
\hline Ekspor & 1796.6 & 1453.9 & 1370.4 & 1546.1 & 1454.5 & 227.4 & 220.1 & (3.2) & (3.5) \\
\hline 1. Migas & 0.0 & 0.0 & 0.0 & 0.0 & 0.0 & 0.0 & 0.0 & 0.0 & 0.0 \\
\hline 2. Non Migas & 1796.6 & 1453.9 & 1370.4 & 1546.1 & 1454.5 & 227.4 & 220.1 & (3.2) & (3.5) \\
\hline Impor & 4113.2 & 3751.4 & 3864.0 & 3166.0 & 3344.9 & 549.6 & 662.3 & 20.5 & (5.7) \\
\hline 1. Migas & 4.7 & 0.1 & 4.1 & 0.2 & 9.8 & - & 6.2 & - & 28.0 \\
\hline 2. Non Migas & 4108.6 & 3751.3 & 3860.0 & 3165.7 & 3335.1 & 549.6 & 656.0 & 19.4 & (5.7) \\
\hline $\begin{array}{l}\text { Neraca } \\
\text { Perdagangan }\end{array}$ & (2 316.6) & (2 297.4) & $(2$ 493.6) & $(1$ 619.9) & (1 890.4) & (322.2) & (442.2) & 37.2 & 0.0 \\
\hline & (4.6) & $(0.1)$ & (4.1) & $(0.2)$ & (9.8) & 0.0 & $(6,)$. & 0.0 & 0.0 \\
\hline 2. Non Migas & (2 312.0) & (2 297.4) & (2 489.5) & (1 619.6) & (1 880.6) & (322.2) & (436.0) & 35.3 & 0.0 \\
\hline
\end{tabular}

Sumber: ITC, 2019 (Diolah)

Berdasarkan Tabel 2, diketahui bahwa ekspor Indonesia ke MERCOSUR pada periode 20142018 didominasi oleh ekspor non migas yang mengalami penurunan rata-rata sebesar 3.5\% per tahun. Selama lima tahun terakhir, impor Indonesia mengalami tren penurunan rata-rata sebesar 5.7\%. Namun jika dibandingkan tahun 2018 periode Jan-Feb impor non migas Indonesia dari MERCOSUR pada tahun 2019 pada periode yang sama mengalami peningkatan sebesar 19.36\%. Kinerja ekspor impor selama periode 2014-2018 tersebut menghasilkan defisit neraca perdagangan. Pada periode Jan-Feb 2019, defisit perdagangan Indonesia dengan MERCOSUR sebesar USD 442,2 juta. Defisit neraca perdagangan meningkat sebesar $37.2 \%$ pada JanFeb 2018/2019.

Berdasarkan pemaparan di atas diketahui bahwa secara kondisi makroekonomi, Indonesia memiliki potensi ekspansi perdagangan yang lebih tinggi ke negara-negara MERCOSUR, namun hingga saat ini neraca perdagangan Indonesia-MERCOSUR masih defisit. Pada sisi lain, perjanjian perdagangan antara ASEAN- 
MERCOSUR di New York pada bulan September 2017 antara Duta Besar Brazil dan Duta Besar Argentina (mewakili MERCOSUR) dengan Perwakilan Kementerian Perdagangan RI, menjadi titik awal pembentukan kerjasama perdagangan Indonesia dengan negara-negara MERCOSUR, dengan bentuk format perjanjian berupa CEPA secara incremental. Pentingnya membina hubungan kerjasama perdagangan dengan MERCOSUR dikarenakan menurunnya hubungan perdagangan antara Indonesia dengan negara-negara MERCOSUR.

Berdasarkan pemaparan tersebut, maka perlu dilakukan penelitian mengenai bagaimana kinerja perdagangan Indonesia dengan negaranegara MERCOSUR, juga terkait faktor-faktor apa saja yang memengaruhi perdagangan Indonesia dengan MERCOSUR. Selanjutnya, juga perlu disusun strategi yang tepat untuk dapat memanfaatkan secara maksimal perjanjian perdagangan antara Indonesia-negara-negara MERCOSUR.

\section{Tujuan}

1. Mengidentifikasi kinerja perdagangan Indonesia-MERCOSUR selama lima tahun terakhir.

2. Menganalisis faktor-faktor yang memengaruhi ekspor Indonesia ke MERCOSUR

3. Merumuskan strategi yang bisa dilakukan oleh Indonesia untuk bisa memanfaatkan kerjasama perdagangan IndonesiaMERCOSUR.

\section{METODOLOGI}

\section{Kerangka Pemikiran Operasional}

Indonesia saat ini tengah aktif menjajaki kemungkinan kerjasama dengan negara-negara non tradisonal, termasuk negara-negara yang berada di kawasan Amerika Latin. Kerjasama dimaksudkan untuk memperluas akses pasar dan mendorong ekspor nasional. Berhasilnya perundingan dengan Chile dan telah dimulainya perundingan kerjasama dengan Peru pada tahun 2017, merupakan langkah positif untuk mewujudkan perluasan akses pasar dan peningkatan ekspor nasional. Oleh karena itu, penjajakan kerjasama ke negara-negara lain perlu dilakukan, diantaranya MERCOSUR, dimana negara-negara anggotanya merupakan negara potensial untuk pasar ekspor Indonesia.

Negara yang termasuk ke dalam negaranegara MERCOSUR yaitu Argentina, Brazil, Paraguay dan Uruguay. Terdapat berbagai perjanjian dagang antara MERCOSUR dengan Indonesia. Ekspor Indonesia ke MERCOSUR pada periode 2012-2016 mengalami penurunan rata-rata sebesar $9,3 \%$ per tahun. Berdasarkan struktur tarif MFN MERCOSUR, hanya 20\% dari nilai total produk ekspor Indonesia yang dikenakan tarif 0\%-5\%, sedangkan $80 \%$ masih terkena tarif di atas 5\%. Hal-hal tersebut menjadi dasar perlu adanya kerjasama Perdagangan Indonesia-MERCOSUR untuk meningkatkan perdaganganya antarnegara.

Berdasarkan hal tersebut, penelitian ini mengidentifikasi kinerja perdagangan Indonesia dengan negara-negara MERCOSUR, analisis faktor-faktor apa saja yang memengaruhi perdagangan Indonesia dengan MERCOSUR, dan terkait strategi yang tepat untuk dapat memanfaatkan secara maksimal perjanjian perdagangan antara Indonesia-MERCOSUR. Untuk menjawab berbagai pertanyaan tersebut, dalam penelitian ini digunakan berbagai metode analisis yaitu: analisis deskriptif kualitatif, analisis regresi dengan panel data dan analisis SWOT, dengan berbagai analisis tersebut dihasilkan suatu rekomendasi kebijakan kerjasama perdagangan Indonesia MERCOSUR. Kerangka pemikiran operasional penelitian disajikan pada Gambar 1. 


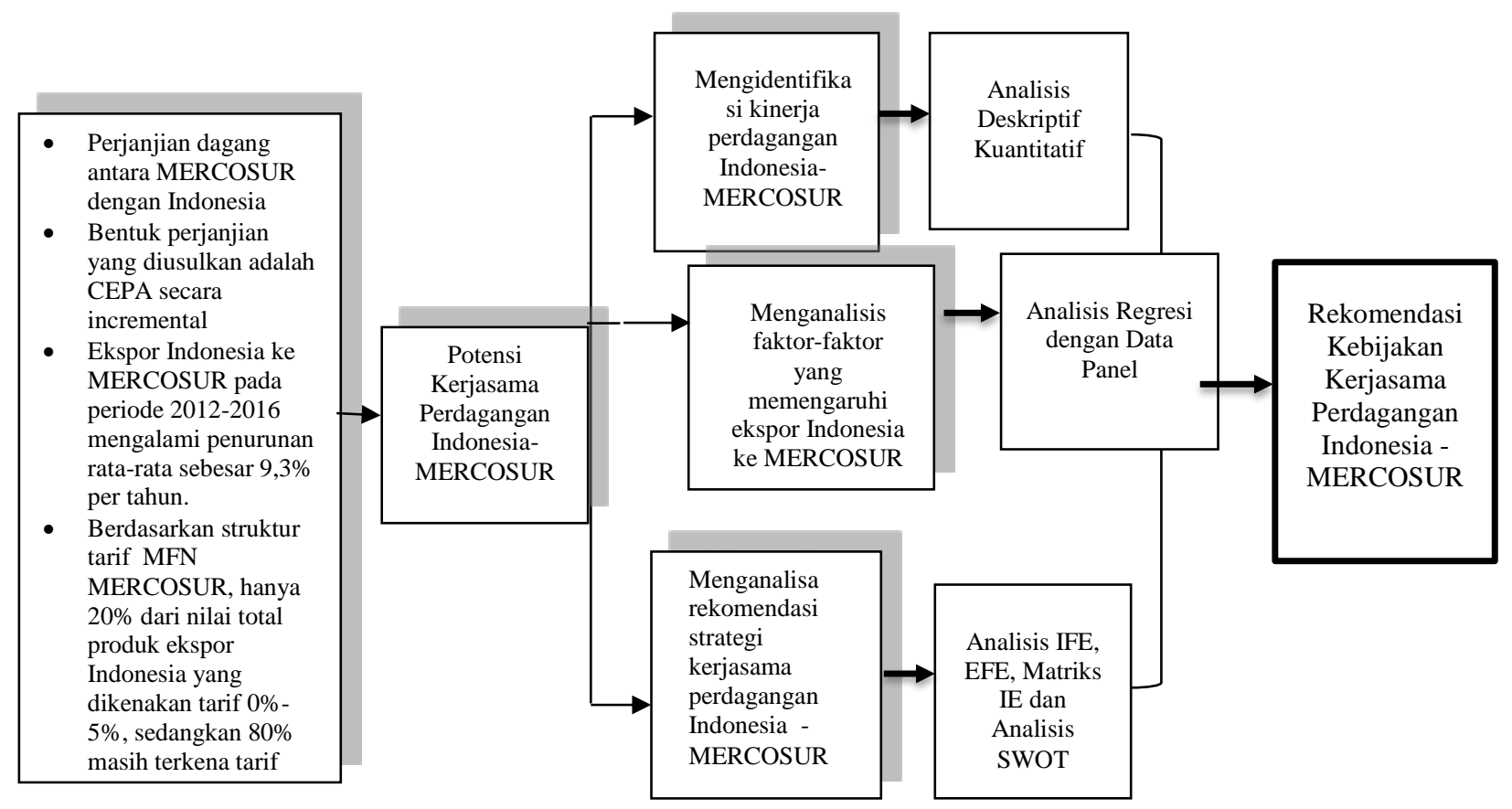

Gambar 1. Kerangka Pemikiran Operasional Penelitian

\section{Jenis dan Sumber Data}

Jenis data yang digunakan dalam penelitian ini adalah data sekunder dan data primer. Data sekunder yang digunakan adalah data komoditas yang diperdagangkan antara Indonesia dengan Negara-Negara MERCOSUR yaitu: Brazil, Argentina, Paraguay, dan Uruguay. Sumber data sekunder menggunakan data-data pada publikasi yang dikeluarkan World Development Indicators (WDI) - World Bank, WITS World Bank, ITC Trade Map, UNCTAD, Kementerian Perdagangan, Badan Pusat Statistik dan kementerian lain yang terkait. Sumber-sumber data dari hasil penelitian atau artikel terdahulu yang relevan.

Data primer digunakan untuk merumuskan rekomendasi strategi Indonesia untuk memanfaatkan kerjasama perdagangan Indonesia-MERCOSUR. Data primer diperoleh dari data survey dan Focus Group Discussion (FGD) dengan Stakeholders terkait perancangan formulasi strategi yang bisa dilakukan oleh Indonesia untuk bisa memanfaatkan kerjasama perdagangan Indonesia-MERCOSUR.

\section{Metode Analisis}

\section{Analisis Deskriptif Kualitatif}

Analisis deskriptif kualitatif digunakan untuk identifikasi kinerja pedagangan IndonesiaMERCOSUR dilakukan dengan mengidentifikasi beberapa hal yaitu: Neraca Perdagangan Indonesia-MERCOSUR, posisi MERCOSUR sebagai negara tujuan ekspor Indonesia ke dunia, produk utama ekspor Indonesia ke MERCOSUR, posisi MERCOSUR sebagai negara asal impor Indonesia dari dunia, komoditas utama impor Indonesia dari MERCOSUR, dan kinerja perdagangan MERCOSUR dengan dunia. Identifikasi dilakukan dengan tabulasi dan dianalisis.

\section{Gravity Model}

Gravity Model adalah model yang digunakan untuk meneliti aliran perdagangan internasional. Volume (atau nilai ekspor) suatu barang dapat dijelaskan oleh variable-variabel ukuran ekonomi (GDP), populasi dan jarak ekonomi dari masingmasing Negara yang melakukan perdagangan (Bergstrand, 1985). 
Dalam penelitian ini volume (atau nilai ekspor) suatu barang dapat dijelaskan oleh variabel-variabel ukuran ekonomi berupa GDP negara-negara MERCOSUR dan GDP Indonesia dan jarak ekonomi Indonesia dengan negaranegara MERCOSUR. Variabel-variabel yang diteliti pada model ini diadopsi dari penelitian lain yang menggunakan gravity model diantaranya yaitu Eita dan Jordan (2007), Dilanchiev (2012), dan Hanoum dan Mulatsih (2016), membentuk persamaan sebagai berikut:

$$
\begin{aligned}
\text { LNEXIt }=\alpha+\beta_{1} \text { LNGDPM }_{\mathrm{jt}}+\beta_{2} \text { LNGDPI }_{\mathrm{t}}+\beta_{3} & \\
\text { dimana : } & \text { LNJE }_{\mathrm{t}}+\mu_{\mathrm{it}} \\
\text { EXIt }= & \text { Nilai ekspor Indonesia ke } \\
& \text { MERCOSUR pada tahun ke-t (US\$) } \\
\text { GDPMjt = } & \text { GDP negara-negara MERCOSUR } \\
& \text { pada tahun } \mathrm{t} \text { (US\$) } \\
\text { GDPIt = } & \text { GDP Indonesia pada tahun t (US\$) } \\
\text { JEt }= & \text { Jarak ekonomi antara Indonesia } \\
& \text { dengan negara-negara MERCOSUR } \\
& (\text { km) } \\
= & \text { error term }
\end{aligned}
$$

$\beta 1$ dan $\beta 2$ diduga memiliki pengaruh positif terhadap aliran ekspor Indonesia ke MERCOSUR, sedangkan $\beta 3$ diduga memiliki pengaruh negatif terhadap aliran ekspor Indonesia ke MERCOSUR.

\section{Analisis SWOT}

Analisis SWOT adalah sebuah metode dalam merumuskan strategis dengan mengevaluasi berbagai bentuk Kekuatan (Strengths), Kelemahan (Weaknesses), Peluang (Opportunities), dan Ancaman (Threats) yang terdapa dalam lingkungan internal maupun eksternal suatu organisasi/kelembagaan dalam penelitian ini adalah sebuah negara, yaitu Indonesia sebagai lingkungan internal, sedangkan negara-negara MERCOSUR yaitu: Brazil, Argentina, Paraguay, dan Uruguay dan faktor lain di luar Indonesia merupakan lingkungan eksternal. Analisis SWOT diterapkan dengan membangun matriks SWOT, yaitu untuk membangun empat jenis strategis berdasarkan kombinasi antara keempat unsur SWOT.

Perumusan strategi potensi pengembangan kerjasama perdagangan Indonesia-MERCOSUR CEPA dilakukan melalui tiga tahap, yaitu tahap masukan (input stage), tahap pencocokan (matching stage) dan tahap pengambilan keputusan (decision stage). Tahap masukan adalah menyimpulkan informasi dasar yang diperlukan untuk merumuskan strategi dengan menggunakan matriks IFE (Internal Factor Evaluation) dan EFE (External Factor Evaluation). Informasi dasar ini diperoleh dari data primer dan data sekunder. Tahap pencocokan merupakan tahapan yang merumuskan strategi, tahap kedua ini menggunakan matriks SWOT. Analisis ini dilakukan dengan menyebar kuesioner yang telah disusun, terdiri dari indikator-indikator internal dan eksternal yang telah dirumuskan sebelumnya dan tambahan indikator-indikator yang dapat diusulkan responden. Selanjutnya dilakukan tahap wawancara kepada beberapa responden yang terdiri dari 8 stakeholders. Matriks SWOT merupakan cara sistematis untuk mengidentifikasikan faktor-faktor dan strategi yang menggambarkan kesesuaian paling baik diantara berbagai alternatif strategi yang ada. Analisis ini didasarkan pada asumsi bahwa suatu strategi yang efektif akan memaksimalkan kekuatan dan peluang serta meminimalkan kelemahan dan ancaman (Rangkuti, 2005).

Analisa SWOT dilakukan berdasarkan asumsi bahwa suatu strategi yang efektif memaksimalkan kekuatan dan peluang, meminimalkan kelemahan dan ancaman. Matriks SWOT terdiri dari sembilan sel dengan empat sel faktor (S, W, O, dan T). Hal ini dapat dilihat pada Tabel 3. 
Tabel 3. Matriks SWOT

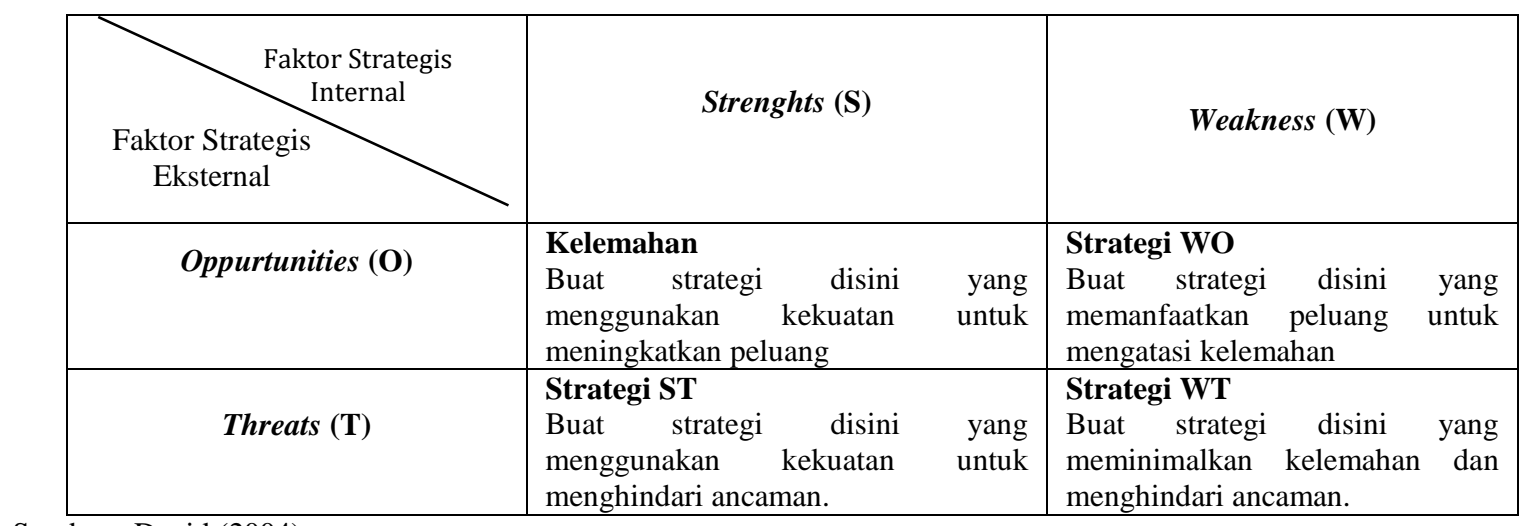

Sumber : David (2004)

\section{HASIL DAN PEMBAHASAN}

Indonesia membuat suatu aliansi perdagangan dengan negara lain terutama negara bagian selatan yang dikenal dengan Kerjasama SelatanSelatan (KSS). Kerja sama ini sudah ada sejak tahun 1978 yang dimaksudkan untuk mempromosikan perdagangan Selatan-Selatan. Indonesia menjalin hubungan perdagangan ke kawasan-kawasan selatan ini salah satunya yaitu Amerika Latin (Marina dan Mulatsih, 2016). Peran Indonesia dalam FEALAC (Forum for East Asia-Latin America Cooperation) dan South-South Economic Coorperation, menjadikan kawasan Amerika Latin sebagai pasar potensial bagi pengembahan ekspor Indonesia (Hanoum dan Mulatsih, 2016).

Menurut David Ricardo (Oktaviani dan Tanti, 2014), perdagangan dapat dilakukan oleh negara yang tidak memiliki keunggulan absolut pada kedua komoditas yang diperdagangkan dengan melakukan spesialisasi produk yang kerugian absolutnya lebih kecil atau memiliki keunggulan komparatif. Negara dapat melakukan spesialisasi dalam produksi dan ekspor komoditi yang memiliki keunggulan absolut lebih kecil dan akan melakukan impor komoditi yang memiliki kerugian absolut lebih besar (Salvatore, 1997). Pentingnya perdagangan antarnegara tergantung pada seberapa besar kesamaan antarnegara atas faktor produksi yang dimiliki (Krugman dan Obstfeld 2009).

Jarak antara Indonesia dengan kawasan Amerika latin yang terlalu jauh menyebabkan tidak semua negara di Amerika Latin merupakan pasar ekspor yang potensial (Wardani dan Mulatsih, 2017). Meskipun demikian, karena ukuran ekonomi (GDP, pendapatan per kapita, dan jumlah penduduk) negara-negara MERCOSUR secara bersamaan cukup besar, maka perdagangan Indonesia-MERCOSUR tetap terjadi dan potensial untuk dikembangkan. Dalam penelitian ini, terdapat empat negara Amerika Latin yang tergabung dalam MERCOSUR yang dianalisis, yaitu: Argentina, Brazil, Paraguay, dan Uruguay. Berikut ini dijabarkan kinerja perdagangan Indonesia dengan negara-negara MERCOSUR.

\section{Analisis Kinerja Perdagangan Indonesia- MERCOSUR}

Kinerja perdagangan Indonesia-MERCOSUR dapat dilihat dari beberapa indikator, yaitu: (a) neraca perdagangan Indonesia ke MERCOSUR; (b) Posisi MERCOSUR sebagai negara tujuan ekspor Indonesia ke dunia (c) Produk utama ekspor Indonesia ke MERCOSUR (d) Struktur tarif dalam perdagangan dengan negara-negara MERCOSUR.

a. Neraca Perdagangan Indonesia ke Negaranegara MERCOSUR

Total perdagangan Indonesia ke negaranegara MERCOSUR pada 2018 didominasi oleh non migas baik dari sisi ekspor maupun impor. Neraca perdagangan indonesia ke MERCOSUR dapat dilihat pada Tabel 4 . 
Tabel 4. Neraca Perdagangan Indonesia dengan Negara-Negara MERCOSUR, Tahun 2018

\begin{tabular}{lrrrr}
\hline \multirow{2}{*}{ Uraian } & \multicolumn{4}{c}{ Dalam Nilai : USD Juta } \\
\cline { 2 - 5 } & Argentina & Brazil & Paraguay & Uruguay \\
\hline Total Perdagangan & $\mathbf{1 ~ 6 7 9 . 8 6}$ & $\mathbf{2 9 4 8 . 1 4}$ & $\mathbf{1 2 3 . 6 0}$ & $\mathbf{4 7 . 7 7}$ \\
Migas & 0.00 & 9.84 & - & - \\
Non Migas & 679.86 & 2938.30 & 123.60 & 47.77 \\
Ekspor & $\mathbf{2 3 8 . 2 8}$ & $\mathbf{1 1 4 5 . 5 9}$ & $\mathbf{3 1 . 9 9}$ & $\mathbf{3 8 . 6 0}$ \\
Migas & 0.00 & 0.00 & - & - \\
Non Migas & 238.28 & 1145.59 & 31.99 & 38.60 \\
Impor & $\mathbf{1 4 4 1 . 5 8}$ & $\mathbf{1 ~ 8 0 2 . 5 4}$ & $\mathbf{9 1 . 6 2}$ & $\mathbf{9 . 1 7}$ \\
Migas & - & 9.84 & - & \\
Non Migas & 1441.58 & 1792.70 & 91.62 & 9.17 \\
Neraca Perdagangan & $\mathbf{( 1 2 0 3 . 3 0 )}$ & $\mathbf{( 6 5 6 . 9 5 )}$ & $(\mathbf{5 9 . 6 3})$ & $\mathbf{2 9 . 4 3}$ \\
Migas & 000 & $(9.84)$ & - & - \\
Non Migas & $(1203.30)$ & $(647.11)$ & $(59.63)$ & 29.43 \\
\hline
\end{tabular}

Sumber: BPS, 2019 (diolah)

Berdasarkan Tabel 4, diketahui bahwa neraca perdagangan Indonesia-MERCOSUR pada tahun 2018 bernilai negatif, kecuali dengan Uruguay. Tingkat defisit neraca perdagangan terbesar dengan MERCOSUR terjadi antara Indonesia dengan Argentina. Jenis produk yang banyak diimpor oleh Indonesia dari Argentina adalah: Other marine fish, frozen, excl. edible fish offal of subheadings 0303.91-99 (HS 03038919), Shark fins, frozen (HS 03039200), dan Other crabs, frozen, fit for human consumption (HS 03061490). Sebaliknya, neraca perdagangan Indonesia dengan Uruguay bernilai positif. Jenis barang yang banyak diekspor oleh Indonesia ke Uruguay yaitu: Refined, bleached and deodorised (RBD) palm kernel stearin, not further prepared (HS. 15162096), Other instruments and appliances, used in medical (HS 90189090), dan Coconuts, desiccated and dried (HS 08011100).

Meskipun neraca perdagangan IndonesiaMERCOSUR sebagian besar bernilai negatif, potensi kerjasama perdagangan antara Indonesia dengan MERCOSUR tetap diperlukan dalam upaya mengurangi defisit neraca perdagangan tersebut. Hal ini sesuai dengan beberapa penelitian yang menunjukkan adanya perdagangan internasional (liberalisasi perdagangan) dalam jangka panjang justru memperbaiki neraca perdagangan diantara sesama negara (Zulkarnaen et al, 2012). Hal ini disebabkan pada kondisi awal sebelum diberlakukannya liberalisasi, neraca perdagangan di hampir seluruh negara yang terlibat sudah mengalami defisit yang jauh lebih besar. Sebagai contoh berdasarkan kajian yang dilakukan oleh Firdaus (2011), defisit neraca perdagangan Indonesia sebelum diberlakukannya liberalisasi perdagangan ASEAN-China mencapai defisit US\$ -4.959 juta, setelah skema liberalisasi menjadi defisit US\$ 378.48 juta. Karena semakin kecilnya defisit neraca perdagangan, hal ini menunjukkan bahwa dengan adanya liberalisasi mampu memperbaiki kinerja perdagangan masing-masing negara yang terlibat.

\section{b. Posisi MERCOSUR Sebagai Negara Tujuan Ekspor Indonesia ke Dunia}

MERCOSUR tidak menempati posisi dalam 20 besar negara tujuan ekspor non migas Indonesia pada tahun 2018. Secara keseluruhan MERCOSUR hanya menempati posisi 25 negara tujuan ekspor non migas Indonesia dengan pangsa ekspor sebesar $0.81 \%$ dari total nilai ekspor Indonesia ke dunia sebesar USD 180,22 milyar. Ekspor Indonesia ke MERCOSUR mengalami penurunan rata-rata sebesar $3.55 \%$ per tahun sepanjang 2014-2018. Data peringkat negara-negara MERCOSUR sebagai negara tujuan ekspor non migas Indonesia dapat dilihat pada Tabel 5. 
Tabel 5. Peringkat Negara-Negara MERCOSUR sebagai Negara Tujuan Ekspor Non Migas Indonesia Tahun 2014-2018

\begin{tabular}{llcccr}
\hline No. Uraian & $\begin{array}{c}\text { Urutan dalam perdagangan } \\
\text { dengan Indonesia pada periode } \\
\mathbf{2 0 1 4 - 2 0 1 8}\end{array}$ & $\begin{array}{c}\text { Nilai } \\
\text { Ekspor } \\
\text { Tahun } \\
\mathbf{2 0 1 8}\end{array}$ & $\begin{array}{c}\text { Trend } \\
\mathbf{( \% )}\end{array}$ & $\begin{array}{c}\text { Share } \\
\mathbf{2 0 1 4 - 2 0 1 8}\end{array}$ & $\begin{array}{c}\text { tahun 2018 } \\
(\mathbf{\%})\end{array}$ \\
\hline & MERCOSUR: & 25 & 1.45 & -3.55 & 0.81 \\
\hline 1 & Argentina & 44 & 0.24 & 1.29 & 0.15 \\
2 & Brazil & 25 & 1.15 & -4.75 & 0.6 \\
3 & Paraguay & 110 & 0.03 & 10.11 & 0.02 \\
4 & Uruguay & 107 & 0.04 & -0.41 & 0.02 \\
\hline
\end{tabular}

Sumber: ITC, 2019 (diolah)

Seperti halnya dengan MERCOSUR secara keseluruhan, Argentina secara parsial juga tidak menempati posisi dalam 20 besar negara tujuan ekspor non migas Indonesia pada tahun 2018, dengan pangsa ekspor hanya sebesar $0.15 \%$ dari total nilai ekspor Indonesia ke dunia. Meskipun demikian, ekspor Indonesia ke Argentina mengalami peningkatan rata-rata sebesar $1.29 \%$ per tahun sepanjang 2014-2018. Pada tahun 2018, Brazil menjadi negara ke-25 tujuan ekspor Indonesia ke dunia, namun tren ekspor Indonesia ke Brazil mengalami penurunan rata-rata sebesar 4.75\% per tahun sepanjang 2014-2018. Seperti halnya dengan Argentina, Paraguay secara parsial juga tidak menempati posisi dalam 20 besar negara tujuan ekspor non migas Indonesia pada tahun 2018. Pangsa ekspor Indonesia ke Paraguay hanya sebesar $0.02 \%$ dari total nilai ekspor Indonesia ke dunia. Meskipun demikian, ekspor Indonesia ke Paraguay mengalami peningkatan rata-rata sebesar $10.11 \%$ per tahun sepanjang 2014-2018. Uruguay secara parsial juga tidak menempati posisi dalam 20 besar negara tujuan ekspor non migas Indonesia pada tahun 2018. Pangsa ekspor Indonesia ke Uruguay hanya sebesar $0.02 \%$ dari total nilai ekspor Indonesia ke dunia, dengan tren penurunan ekspor rata-rata sebesar $0.41 \%$ per tahun sepanjang 2014-2018.

\section{c. Produk Utama Ekspor Indonesia ke MERCOSUR}

Produk Ekspor utama Indonesia ke Argentina didominasi oleh produk kelapa sawit, karet, onderdil kendaraan bermotor, serat buatan, alas kaki, dan kelapa. Sepuluh besar produk ekspor utama tersebut dengan nilai USD 977 juta mencapai $48 \%$ dari total ekspor Indonesia ke Argentina. Posisi pertama ditempati oleh Technically Specified Natural Rubber (TSNR) 20 dengan nilai ekspor pada tahun 2018 sebesar USD 5.27 juta. Meskipun demikian selama periode 2014-2018 ekspor komoditas tersebut mengalami penurunan sebesar $6.82 \%$ per tahun. Komoditas utama ekspor nonmigas Indonesia ke Argentina dapat dilihat pada Tabel 6.

Tabel 6. Komoditas Utama Ekspor Nonmigas Indonesia ke Argentina

\begin{tabular}{|c|c|c|c|c|c|c|c|c|}
\hline & \multirow{2}{*}{ HS } & \multicolumn{5}{|c|}{ Dalam Nilai : USD Juta } & \multirow{2}{*}{$\begin{array}{l}\text { Trend (\%) } \\
\text { 2014-2018 }\end{array}$} & \multirow{2}{*}{$\begin{array}{c}\text { Share } \\
\text { Tahun } \\
2018(\%)\end{array}$} \\
\hline & & 2014 & 2015 & 2016 & 2017 & 2018 & & \\
\hline \multicolumn{2}{|c|}{ Non Migas } & 237 & 237 & 220 & 266 & 238 & 1.25 & 100.00 \\
\hline 1 & 40012220 & 53.44 & 40.21 & 35.16 & 47,42 & 34.56 & -6.82 & 14.52 \\
\hline 2 & 84073472 & 18.17 & 14.46 & 10.84 & 20,23 & 22.71 & 8.13 & 9.54 \\
\hline 3 & 64061090 & 13.67 & 12.83 & 8.42 & 8,85 & 10.9 & -7.91 & 4.58 \\
\hline 4 & 64041190 & 2.76 & 3.9 & 7.35 & 8,21 & 8.9 & 36.15 & 3.74 \\
\hline 5 & 87084026 & 3.12 & 11.64 & 12.19 & 9,35 & 8.57 & 19.74 & 3.60 \\
\hline 6 & 55092100 & 8.92 & 8.22 & 7.5 & 10,24 & 7 & -2.62 & 2.94 \\
\hline 7 & 64039910 & 3.21 & 5.25 & 5.76 & 4,56 & 6.02 & 11.81 & 2.53 \\
\hline 8 & 64062010 & 5.53 & 4.37 & 4.28 & 4,41 & 5.71 & 0.73 & 2.40 \\
\hline 9 & 84213120 & 0.2 & 0.6 & 2.97 & 3,82 & 5.44 & 132.97 & 2.29 \\
\hline \multirow[t]{3}{*}{10} & 54023300 & 6.93 & 8.15 & 8.07 & 5,19 & 5.01 & -10.42 & 2.11 \\
\hline & Sub Total & 115.95 & 109.63 & 102.54 & 122,28 & 114.82 & 0.90 & 48.24 \\
\hline & Others & 121.05 & 127.37 & 117.46 & 143,72 & 123.18 & 1.57 & 51.76 \\
\hline
\end{tabular}


Keterangan:

40012220 : Technically Specified Natural Rubber (TSNR) 20

84073472 : Full assembled,spark- reciprocating piston engines,cylindercapacity $2000<c c<=3000$, for vehicles of heading 87

64061090 : Uppers\&parts thereof,oth than stiffeners\&not fitted withmetal toe-cap

64041190 : Sports footwear not fitted with spikes/wrstling/weightlifting/the like oth

87084026 : Gear boxes, assembled for vehicles of heading 8703

55092100 : Containing $85 \%$ or more by weight of polyester staple fibres, single yarn

64039910 : Footwear made on a base/platform of wood not having innersole/protective metal toe cap, not covering the ankle

64062010 : Parts of footwear with outer soles \& heels, of rubber

84213120 : Intake air filters of internal combustion engines for motorvehicles of Chapter 87

54023300 : Textured yarn of polyesters

Perdagangan antara Indonesia dan Brazil juga didominasi dengan didominasi oleh produk kelapa sawit, karet, onderdil kendaraan bermotor, dan serat buatan. Sepuluh besar produk ekspor utama dengan nilai USD 977 juta mencapai 60.94\% dari total ekspor Indonesia ke Brazil. Posisi pertama adalah Palm kernel oil, RBD dengan nilai ekspor pada 2018 sebesar USD 141.47 juta dan pangsa ekspor sebesar $12.35 \%$. Meskipun demikian selama periode 2014-2018 ekspor komoditas tersebut mengalami tren penurunan sebesar $0.21 \%$ pertahun. Komoditas utama ekspor nonmigas Indonesia ke Brazil dapat dilihat pada Tabel 7 .

Tabel 7. Komoditas Utama Ekspor Nonmigas Indonesia ke Brazil

\begin{tabular}{|c|c|c|c|c|c|c|c|c|}
\hline \multirow[b]{2}{*}{ No } & \multirow[b]{2}{*}{ HS } & \multicolumn{5}{|c|}{ Dalam Nilai : USD Juta } & \multirow{2}{*}{$\begin{array}{c}\text { Trend } \\
(\%) \\
2014-2018\end{array}$} & \multirow{2}{*}{$\begin{array}{c}\text { Share } \\
\text { Tahun } \\
2018(\%)\end{array}$} \\
\hline & & 2014 & 2015 & 2016 & 2017 & 2018 & & \\
\hline \multicolumn{2}{|c|}{\begin{tabular}{|l} 
Non Migas \\
\end{tabular}} & 1498.17 & 1166.01 & 1102.04 & 1225.38 & 1145.59 & -4.75 & 100.00 \\
\hline 1 & 15132995 & 170.70 & 136.86 & 198.47 & 195.10 & 141.47 & -0.21 & 12.35 \\
\hline 2 & 40012220 & 181.21 & 131.60 & 122.16 & 161.28 & 127.49 & -4.88 & 11.13 \\
\hline 3 & 87084026 & 119.72 & 135.78 & 106.28 & 118.07 & 115.83 & -2.04 & 10.11 \\
\hline 4 & 55101100 & 108.46 & 100.15 & 96.59 & 81.26 & 67.93 & -10.82 & 5.93 \\
\hline 5 & 55092100 & 62.01 & 32.19 & 24.23 & 40.52 & 57.28 & 0.72 & 5.00 \\
\hline 6 & 85312000 & 0.04 & 0.06 & 0.04 & 4.71 & 46.04 & 549.97 & 4.02 \\
\hline 7 & 87141090 & 6.77 & 11.94 & 21.35 & 30.36 & 40.38 & 56.90 & 3.52 \\
\hline 8 & 55095100 & 50.94 & 29.76 & 39.64 & 31.43 & 40.06 & -4.17 & 3.50 \\
\hline 9 & 15119020 & & - & - & 25.04 & 37.00 & - & 3.23 \\
\hline \multirow[t]{3}{*}{10} & 40111000 & 29.52 & 9.45 & 7.98 & 17.53 & 24.62 & 2.58 & 2.15 \\
\hline & Sub Total & 729.37 & 587.78 & 616.73 & 705.30 & 698.12 & 0.95 & 60.94 \\
\hline & Others & 768.81 & 578.24 & 485.31 & 520.08 & 447.48 & -11.21 & 39.06 \\
\hline
\end{tabular}

Sumber: ITC, 2019 (diolah)

Keterangan:

15132995 : Palm kernel oil, RBD

$40012220:$ TSNR 20

87084026 : Gear boxes, assembled for vehicles of heading 8703

55101100 : Containing $85 \%$ or more by weight of artificial staple fibres, single yarn

55092100 : Containing $85 \%$ or more by weight of polyester staple fibres, single yarn

85312000 : Indicator panel incorporating LCD/LED

87141090 : Other of motorcycles (including mopeds)

55095100 : Other yarn, of polyester staple fibres, Mixed mainly or solely with artificial staple fibres

15119020 : Refined palm oil

40111000 : New pneumatic tyres, of rubber, of a kind used on motor cars (including station wagons and racing cars 
Perdagangan antara Indonesai dan Paraguay didominasi oleh produk tembakau dan rokok, kendaraan bermotor, plastik dan serat buatan. Sepuluh besar produk ekspor utama dengan nilai USD 26.50 juta mencapai $82.84 \%$ dari total ekspor Indonesia ke Paraguay. Posisi pertama adalah Cigarettes containing tobacco, oth than beedies and clove cigarettes dengan nilai ekspor pada 2018 sebesar USD 15.37 juta dengan pangsa ekspor sebesar $48.06 \%$. Selama periode 2014-2018 ekspor komoditas tersebut mengalami tren peningkatan sebesar $14.24 \%$ pertahun. komoditas utama ekspor nonmigas Indonesia ke Paraguay dapat dilihat pada Tabel 8 .

Tabel 8. Komoditas Utama Ekspor Non migas Indonesia ke Paraguay

\begin{tabular}{|c|c|c|c|c|c|c|c|c|}
\hline \multirow{2}{*}{ No } & \multirow{2}{*}{ HS } & \multicolumn{5}{|c|}{ Dalam Nilai : USD Juta } & \multirow{2}{*}{$\begin{array}{l}\text { Trend }(\%) \\
2014-2018\end{array}$} & \multirow{2}{*}{$\begin{array}{c}\text { Share } \\
\text { Tahun } 2018 \\
(\%)\end{array}$} \\
\hline & & 2014 & 2015 & 2016 & 2017 & 2018 & & \\
\hline \multicolumn{2}{|c|}{ Non Migas } & 19.62 & 22.29 & 18.90 & 21.97 & 31.99 & $\mathbf{1 0 . 1 1}$ & 100.00 \\
\hline 1 & 24022090 & 8.59 & 9.55 & 10.62 & 11.29 & 15.37 & 14.24 & 48.05 \\
\hline 2 & 87032259 & - & - & - & - & 3.99 & - & 12.47 \\
\hline 3 & 85042329 & - & - & - & - & 1.97 & - & 6.16 \\
\hline 4 & 39202010 & 0.92 & 0.85 & 0.77 & 1.27 & 1.39 & 13.06 & 4.35 \\
\hline 5 & 39269099 & - & 0.67 & 0.75 & 0.97 & 1.01 & - & 3.16 \\
\hline 6 & 85287111 & 0.66 & 2.95 & 0.53 & 0.00 & 0.64 & -52.42 & 2.00 \\
\hline 7 & 85071096 & 0.67 & 1.00 & 0.61 & 0.53 & 0.56 & -9.57 & 1.75 \\
\hline 8 & 64039910 & 0.24 & 0.21 & 0.27 & 0.66 & 0.54 & 31.33 & 1.69 \\
\hline 9 & 84212321 & 0.51 & 0.47 & 0.45 & 0.77 & 0.52 & 5.20 & 1.63 \\
\hline \multirow[t]{3}{*}{10} & 64041190 & 0.40 & 0.22 & 0.06 & 0.39 & 0.51 & 11.07 & 1.59 \\
\hline & Sub Total & 12.00 & 15.93 & 14.04 & 15.88 & 26.50 & 17.14 & 82.84 \\
\hline & Others & 7.62 & 6.36 & 4.86 & 6.08 & 5.49 & -6.76 & 17.16 \\
\hline
\end{tabular}

Sumber: ITC, 2019 (diolah)

Keterangan:

24022090 : Cigarettes containing tobacco, oth than beedies and clove cigarettes

87032259 : Oth motor car (Station Wagon\&sport cars) Of Not 4WDgasoline of a cylinder 1,000 <cc $<=1,500$, Not $C K D$

85042329 : Liquid dielectric transformers, power capacity $>30.000 \mathrm{kVA}$

39202010 : Biaxially oriented polypropylene (BOPP) film

39269099 : Other articles of plastics \& other materials of headings 39.01 to 39.14. oth than 3926.10.00-3926.90.92

85287111 : Reception appratus for television, set top box which havea communication function,mains operated

85071096 : Lead-acid accumulators,used starting piston engines fornot aircraft,voltage $6 \mathrm{~V} / 12 \mathrm{~V}$, capacity $<=200 \mathrm{AH}$, height $>23 \mathrm{~cm}$

64039910 : Footwear made on a base/platform of wood not having innersole/protective metal toe cap, not covering the ankle

84212321 : Oil filters of internal combustion engines for motor vhclof Chapter 87

64041190 : Sports footwear not fitted with spikes/wrstling/weightlifting/the like oth

Perdagangan antara Indonesai dan Uruguay didominasi dengan didominasi oleh produk kelapa sawit dan turunannya, kelapa, kendaraan bermotor, dan alas kaki. 10 besar produk ekspor utama dengan nilai USD 17.94 juta mencapai $46.48 \%$ dari total ekspor Indonesia ke Uruguay. Posisi pertama adalah Refined, bleached and deodorised (RBD) palm kernel stearin, not further prepared dengan nilai ekspor pada 2018 sebesar USD 3.41 juta dengan pangsa ekspor sebesar $8.83 \%$. komoditas utama ekspor nonmigas Indonesia ke Uruguay dapat dilihat pada Tabel 9. 
Tabel 9. Komoditas Utama Ekspor Nonmigas Indonesia ke Uruguay

\begin{tabular}{|c|c|c|c|c|c|c|c|c|}
\hline \multirow{2}{*}{ No } & \multirow{2}{*}{ HS } & \multicolumn{5}{|c|}{ Dalam Nilai : USD Juta } & \multirow{2}{*}{$\begin{array}{l}\text { Trend (\%) } \\
\text { 2014-2018 }\end{array}$} & \multirow{2}{*}{$\begin{array}{c}\text { Share } \\
\text { Tahun } 2018 \\
(\%)\end{array}$} \\
\hline & & 2014 & 2015 & 2016 & 2017 & 2018 & & \\
\hline \multicolumn{2}{|c|}{ Non Migas } & 41.9 & 28.58 & 29.94 & 32.32 & 38.6 & -0.41 & 100.00 \\
\hline 1 & 15162096 & - & - & - & 2.12 & 3.41 & - & 8.83 \\
\hline 2 & 90189090 & - & - & 0.01 & 0.47 & 2.93 & - & 7.59 \\
\hline 3 & 8011100 & 1.52 & 0.73 & 0.59 & 1.26 & 1.96 & 11 & 5.08 \\
\hline 4 & 87032259 & - & - & - & 0.58 & 1.92 & - & 4.97 \\
\hline 5 & 64041190 & 1,1 & 1.13 & 1.16 & 1 & 1.43 & 4.15 & 3.70 \\
\hline 6 & 64061090 & - & 0.25 & - & 0.91 & 1.36 & - & 3.52 \\
\hline 7 & 85287111 & 0.92 & 0.99 & 0.19 & 0.19 & 1.33 & -8.64 & 3.45 \\
\hline 8 & 84433221 & - & - & - & 0.66 & 1.22 & - & 3.16 \\
\hline 9 & 15162054 & - & - & - & 0.55 & 1.2 & - & 3.11 \\
\hline \multirow[t]{3}{*}{10} & 15119031 & 0.13 & 0.05 & 0.49 & 0.67 & 1.18 & 100.6 & 3.06 \\
\hline & Sub Total & 3.66 & 3.16 & 2.43 & 8.41 & 17.94 & 51.54 & 46.48 \\
\hline & Others & 38.23 & 25.42 & 27.5 & 23.91 & 20.67 & -12.12 & 53.55 \\
\hline
\end{tabular}

Sumber: ITC, 2019 (diolah)

Keterangan:

15162096 : Refined, bleached and deodorised (RBD) palm kernel stearin, not further prepared

90189090 : Other instruments and appliances, used in medical

08011100 : Coconuts, desiccated and dried

87032259 : Oth motor car (Station Wagon\&sport cars) Of Not 4WDgasoline of a cylinder $1,000<c c<=1,500$, Not CKD

64041190 : Sports footwear not fitted with spikes/wrstling/weightlifting/the like oth 64061090 : Uppers\&parts thereof,oth than stiffeners\&not fitted withmetal toe-cap

85287111 : Reception appratus for television,set top box which havea communication function, mains operated

84433221 : Printer ink-jet printers, colour, capable of connect to anauto data processing mach/to a network

15162054 : Vegetable fats \& oils \& their fractions of groundnuts, palm oil \& coconuts, interesterified, not further prepared

15119031 : Solid fractions of refined palm oil, with iodine value 30 or more, but less than 40

d. Struktur Tarif dalam Perdagangan dengan Negara-Negara MERCOSUR

Dalam kegiatan perdagangan dengan Indonesia, negara-negara MERCOSUR mengenakan tarif impor terhadap barang ekspor dari Indonesia. Sebagian besar jenis produk impor dari Indonesia dikenakan tarif impor dalam bentuk tarif ad valorem dan sebagian kecil dalam bentuk tarif spesifik. Namun, dari sisi nilai ekspor, beberapa negara menunjukkan kecenderungan yang berbeda. Argentina banyak mengimpor produk Indonesia yang dikenakan tarif spesifik. Meskipun jenis barang yang dikenakan tarif spesifik hanya 50 jenis, namun 50 jenis barang tersebut merupakan $50.3 \%$ dari nilai ekspor Indonesia ke Argentina. Sementara itu, tarif ad valorem diterapkan pada produk dengan nilai ekspor tertinggi Indonesia ke Brazil, Paraguay dan Uruguay, namun dengan struktur yang berbeda. Brazil dan Paraguay memiliki struktur tarif yang sama terhadap nilai ekspor Indonesia, dimana nilai impor yang tinggi dilakukan pada produk Indonesia dengan tarif sebesar $10-20 \%$. Sementara itu, sebagian besar impor Uruguay dari Indonesia (38.17\%) merupakan produk-produk dengan tarif impor sebesar 5-10\%. Sebagian lain impor Argentina, Brazil, Paraguay dan Uruguay merupakan produk dengan besaran tarif ad valorem yang beragam.

Dalam mengimpor dari negara-negara MERCOSUR, Indonesia pun melakukan hal yang sama, yakni memberlakukan tarif impor. Namun, tarif impor yang diberlakukan seluruhnya adalah 
tarif ad valorem. Dalam melakukan impor dari Argentina, Brazil dan Paraguay, sebagian besar nilai impor diperoleh dari produk dengan tarif impor sebesar 0-5\%. Sementara dalam melakukan impor dari Uruguay, sebagian besar nilai impor diperoleh dari mengimpor produk dengan tarif impor $0 \%$.

\section{Faktor-Faktor yang Memengaruhi Ekspor Indonesia ke MERCOSUR}

Hasil estimasi model tersebut pada Tabel 3 memiliki nilai $R$-squared sebesar 0.992 yang menunjukkan bahwa $99.2 \%$ model tersebut dapat dijelaskan oleh variabel-variabel independen pada model, sedangkan sisanya sebesar $0.8 \%$ dijelaskan di luar model. Model yang digunakan dalam ekpor Indonesia ke MERCOSUR adalah sebagai berikut:

$$
\begin{aligned}
\text { LNEXIt }= & -0.851132+0.763327 \text { LNGDPM }_{\mathrm{jt}}+ \\
& 0.030928 \text { LNGDPI }_{\mathrm{t}}+0.034629 \\
& \mathrm{LNJE}_{\mathrm{t}}+\mu_{\mathrm{it}}
\end{aligned}
$$

Estimasi pemilihan model terbaik dilakukan dengan uji Hausman dan uji Chow untuk memilih random effect model, fixed effect model, atau pooled least square (PLS). Hasil menunjukkan bahwa probabiltas uji Hausman sebesar 0,000 lebih kecil dari alpha $(\alpha) 1 \%$, sehinga dapat disimpulkan cukup bukti untuk menolak $\mathrm{H}_{0}$, sehingga model yang dipilih adalah fixed effect model. Hasil uji Chow menunjukkan hal yang sama untuk menolak hipotesis nol, yakni probabilitias 0,00 kurang dari $\alpha(0,05)$ sehingga model yang dipakai adalah fixed effect.

Berdasarkan hasil uji multikolinearitas, nilai korelasi antar peubah independen lebih kecil dari 0.8 , sehingga tidak terjadi multikolinearitas. Hasil uji normalitas menunjukkan bahwa nilai probabilitas sebesar $0.248>0.05$ dan nilai JarqueBera sebesar 2.830>0.05 sehingga model nilai ekspor Indonesia ke MERCOSUR telah memiliki error terms yang menyebar normal. Berdasarkan uji heteroskedastisitas, diketahui bahwa nilai prob $<0.05$, sehingga terjadi heteroskedastisitas, namun karena estimasi model telah menggunakan pembobotan cross-section, sehingga masalah heteroskedastisitas dapat diabaikan.

GDP negara MERCOSUR (negara tujuan ekspor Indonesia) mempunyai hubungan positif dan signifikan terhadap nilai ekspor komoditi Indonesia. GDP Indonesia mempunyai hubungan positif dan tidak signifikan dengan nilai ekspor komoditi Indonesia ke MERCOSUR. Hasil estimasi memperlihatkan bahwa ketika terjadi kenaikan GDP Indonesia sebesar 1\% maka akan terjadi peningkatan nilai ekspor komoditi Indonesia sebesar $0.030928 \%$ (cateris paribus).

Nilai koefisien variabel jarak ekonomi adalah sebesar 0.034629 yang mengindikasikan bahwa jika jarak ekonomi Indonesia dengan negara tujuan ekspor meningkat sebesar satu persen maka akan terjadi peningkatan ekspor Indonesia ke MERCOSUR sebesar 0,03\% (cateris paribus). Tanda koefisien variabel ekonomi tersebut tidak sesuai dengan hipotesis, namun hasil penelitian terdahulu oleh Lawless dan Whelan (2007) meneliti hubungan jarak dan ekspor dengan menggunakan data Amerika Serikat tahun 2000. Hasil penelitian menunjukkan bahwa jarak dapat berpengaruh secara positif terhadap ekspor.

Lawless dan Whelan (2007) menemukan bahwa untuk melakukan ekspor ke luar negeri, perusahaan-perusahaan di Amerika Serikat harus menaikkan biaya tetap (fixed cost) jika jarak dari tujuan ekspor semakin jauh. Agar tetap mendapat keuntungan dari peningkatan biaya tersebut, maka perusahaan-perusahaan Amerika Serikat tersebut akan meningkatkan volume dan nilai perdagangan. Oleh karena itu, berdasarkan fenomena ini Lawless dan Whelan (2007) menegaskan bahwa jarak dapat berpengaruh positif terhadap ekspor. Dengan demikian, berdasarkan penelitian di atas, secara umum dapat diprediksi bahwa hubungan jarak geografis antara Indonesia dengan negara MERCOSUR dapat meningkatkan ataupun menurunkan ekspor Indonesia ke MERCOSUR.

Tabel 10. Hasil Estimasi Gravity Model Nilai Ekspor Indonesia ke MERCOSUR

\begin{tabular}{lrrrr}
\hline \multicolumn{1}{c}{ Variable } & Coefficient & Std. Error & t-Statistic & Prob. \\
\hline $\mathrm{C}$ & -0.851132 & 1.680 .707 & -0.506413 & 4,27569 \\
LNGDPM $_{\mathrm{it}}$ & 0.763327 & 0.044986 & 1.696 .826 & $0.00000^{*}$ \\
\hline
\end{tabular}




\begin{tabular}{lrlrr}
\hline \multicolumn{1}{c}{ Variable } & Coefficient & Std. Error & t-Statistic & Prob. \\
\hline LNGDPI $_{\mathrm{t}}$ & 0.030928 & 0.145241 & 0.212945 & 5.78194 \\
LNJE $_{\mathrm{t}}$ & 0.034629 & 0.16889 & 0.205038 & 5.82431 \\
\hline R-squared & 0.992043 & Mean dependent var & 3722.305 \\
Adjusted $R$-squared & 0.99138 & S.D. dependent var & 133.585 \\
S.E. of regression & 0.124023 & Akaike info criterion & - \\
& & & \\
Sum squared resid & 0.553739 & Schwarz criterion & 1.242 .065 \\
& & & - \\
Log likelihood & 288.413 & Hannan-Quinn criter. & & 1.073 .177 \\
F-statistic & 1496.19 .00 & Durbin-Watson stat & -1.181 \\
Prob $(F$-statistic) & 0,000 & & 0.128051 \\
Keterangan : Signifikan pada taraf nyata $1 \%(*)$ & & & \\
\hline
\end{tabular}

\section{Strategi Pengembangan Kerjasama Perdagangan Indonesia-MERCOSUR}

Dalam memanfaatkan kerjasama perdagangan Indonesia-MERCOSUR, perlu diidentifikasi halhal yang berasal dari internal dan eksternal Indonesia. Kondisi internal perlu dianalisis untuk mengetahui bagaimana kondisi Indonesia sehingga mampu membuat perbaikan diri untuk memanfaatkan kerjasama yang terjalin dengan negara-negara MERCOSUR, sedangkan analisis kondisi eksternal diperlukan dalam upaya untuk mengidentifikasi kondisi di luar yang tidak terjangkau oleh Indonesia dalam upaya memaksimalkan manfaat perdagangan dengan negara-negara MERCOSUR. Berikut ini akan dijabarkan hasil analisis faktor internal dan eksternal dalam pengembangan kerjasama perdagangan Indonesia-MERCOSUR.

Tabel 11. Matriks IFE Pengembangan Kerjasama Perdagangan Indonesia-MERCOSUR

\begin{tabular}{|c|c|c|c|c|}
\hline No & Faktor Internal & Rating & Bobot & $\begin{array}{c}\text { Skor } \\
\text { Bobot }\end{array}$ \\
\hline \multicolumn{5}{|c|}{ Kekuatan } \\
\hline 1 & $\begin{array}{l}\text { Keunggulan komparatif produk-produk Indonesia di pasar } \\
\text { negara-negara MERCOSUR }\end{array}$ & 4 & 0.13 & 0.53 \\
\hline 2 & $\begin{array}{l}\text { Ketersedian modal dan teknologi dalam peningkatan kapasitas } \\
\text { produksi sektor perekonomian di Indonesia }\end{array}$ & 3 & 0.11 & 0.32 \\
\hline 3 & $\begin{array}{l}\text { Kualitas Sumberdaya Manusia Indonesia dalam mendukung } \\
\text { produktivitas dan daya saing sektor }\end{array}$ & 3 & 0.08 & 0.24 \\
\hline 4 & Pertumbuhan ekonomi Indonesia & 3 & 0.12 & 0.36 \\
\hline \multicolumn{2}{|c|}{ Total Kekuatan } & & & 1.45 \\
\hline \multicolumn{5}{|c|}{ Kelemahan } \\
\hline 5 & Infrastruktur fisik, logistik, dan standar mutu ekspor Indonesia & 1 & 0.16 & 0.16 \\
\hline 6 & $\begin{array}{l}\text { Tarif yang ditetapkan Indonesia untuk negara-negara } \\
\text { MERCOSUR }\end{array}$ & 2 & 0.07 & 0.13 \\
\hline 7 & Pangsa pasar Indonesia di negara-negara MERCOSUR & 1 & 0.05 & 0.05 \\
\hline 8 & Defisit Neraca Perdagangan Indonesia-MERCOSUR & 2 & 0.12 & 0.24 \\
\hline 9 & $\begin{array}{l}\text { Keberadaan Export Promotion Agency Indonesia di negara- } \\
\text { negara MERCOSUR }\end{array}$ & 1 & 0.16 & 0.16 \\
\hline \multirow{2}{*}{\multicolumn{3}{|c|}{ Total Kelemahan }} & & 0.75 \\
\hline & & & 1.00 & 2.20 \\
\hline
\end{tabular}

Sumber: Hasil Analisis (2019)

\section{a. Analisis Faktor Internal (Internal Factor Evaluation)}

Dari hasil akhir analisis matriks IFE, untuk elemen kekuatan diperoleh nilai indeks akumulatif skor sebesar 145, sedangkan nilai akhir bobot skor untuk elemen kelemahan sebesar 0.75. Hal ini menunjukkan bahwa responden memberikan respon yang cukup tinggi terhadap faktor kekuatan dan respon yang kecil kepada faktor kelemahan, sedangkan total nilai bobot skor untuk faktor strategis internal sebesar 2.20. Hasil analisis tersebut menunjukkan bahwa pengembangan kerjasama perdagangan Indonesia-MERCOSUR di atas rata-rata dalam 
kekuatan internal secara keseluruhannya, nilai bobot skor untuk elemen kekuatan lebih besar dari nilai bobot skor elemen kelemahan, maka dapat dinyatakan bahwa dalam pengembangan kerjasama perdagangan Indonesia-MERCOSUR kekuatan yang dimiliki Indonesia mampu mengatasi kelemahan yang ada. Hasil akhir dari analisis IFE dapat dilihat pada Tabel 11.

Berdasarkan matriks IFE diatas dapat dijelaskan lebih rinci tentang faktor-faktor yang mempengaruhi pengembangan kerjasama perdagangan Indonesia-MERCOSUR, baik yang termasuk elemen kekuatan dan elemen kelemahan, yaitu sebagai berikut:

\section{Faktor Kekuatan}

Keunggulan komparatif produk-produk Indonesia di pasar negara-negara MERCOSUR memiliki bobot 0.53 , skor ini merupakan skor tertinggi dalam faktor kekuatan, dan menunjukkan bahwa faktor ini memiliki dampak yang sangat penting terhadap pengembangan kerjasama perdagangan Indonesia-MERCOSUR, jika dibandingkan dengan faktor kekuatan lain yang dimiliki Indonesia. Nilai rating 4 menunjukkan bahwa bahwa faktor keunggulan komparatif yang dimiliki Indonesia memberi pengaruh yang sangat besar terhadap pengembangan kerjasama perdagangan Indonesia-MERCOSUR.

\section{Faktor Kelemahan}

Defisit neraca perdagangan IndonesiaMERCOSUR memiliki skor 0.24 , menunjukkan bahwa faktor ini merupakan kelemahan yang sangat besar dalam pengembangan kerjasama perdagangan Indonesia-MERCOSUR jika dibanding dengan faktor kelemahan lain yang dimiliki Indonesia. Kondisi neraca perdagangan Indonesia dengan negara-negara MERCOSUR yang semakin menurun menunjukkan melemahnya perdagangan Indonesia dan NegaraNegara MERCOSUR dalam beberapa tahun terakhir. Secara umum kondisi di Indonesia belum mendukung oleh iklim bersaing yang kondusif dalam perdagangan dengan negaranegara MERCOSUR seperti kemampuan industri domestik, kondisi tarif, dan pangsa pasar indonesia menjadi kelemahan dalam pengembangan perdagangan Indonesia dengan negara-negara MERCOSUR saat ini.

\section{b. Analisis Faktor Eksternal (External Factor Evaluation)}

Dari hasil akhir analisa matriks EFE untuk elemen peluang diperoleh nilai indeks kumulatif skor sebesar 1.36, sedangkan nilai akhir bobot skor untuk elemen ancaman sebesar 1.11. Hal ini menunjukkan bahwa responden memberikan respon yang cukup tinggi terhadap faktor ancaman dan respon yang lebih kecil terhadap faktor peluang. Total nilai bobot skor untuk faktor strategis eksternal sebesar 2.47. Dari hasil tersebut, dengan nilai bobot skor untuk elemen peluang lebih besar dari bobot skor elemen ancaman, maka dapat disimpulkan bahwa dalam pengembangan kerjasama perdagangan Indonesia-MERCOSUR, kedua belah pihak harus dapat mengatasi berbagai ancaman yang ada. Untuk mengetahui lebih jelas hasil akhir dari analisis EFE dapat dilihat pada Tabel 12.

Tabel 12. Matriks EFE Pengembangan Kerjasama Perdagangan Indonesia-MERCOSUR

\begin{tabular}{|c|c|c|c|c|}
\hline No & Faktor Eksternal & Rating & Bobot & Skor Bobot \\
\hline \multicolumn{5}{|c|}{ Peluang } \\
\hline 1 & Permintaan produk Indonesia di pasar negara-negara MERCOSUR & 4 & 0.09 & 0.36 \\
\hline 2 & Daya saing komoditas barang dan jasa negara-negara MERCOSUR & 3 & 0.08 & 0.24 \\
\hline 3 & Stabilitas ekonomi, sosial, dan politik di negara-negara MERCOSUR & 4 & 0.19 & 0.76 \\
\hline & Total Peluang & & & 1.36 \\
\hline \multicolumn{5}{|c|}{ Ancaman/Tantangan } \\
\hline 4 & Jarak antara Indonesia dan negara-negara MERCOSUR & 1 & 0.17 & 0.17 \\
\hline 5 & $\begin{array}{l}\text { Kerjasama negara MERCOSUR dengan negara lain dalam berbagai } \\
\text { bidang }\end{array}$ & 2 & 0.12 & 0.24 \\
\hline 6 & $\begin{array}{l}\text { Kebijakan tarif negara-negara MERCOSUR terhadap produk dari } \\
\text { Indonesia }\end{array}$ & 2 & 0.10 & 0.21 \\
\hline 7 & $\begin{array}{l}\text { Adanya kebijakan Non -Tariff Measure di negara-negara } \\
\text { MERCOSUR }\end{array}$ & 2 & 0.11 & 0.22 \\
\hline 8 & $\begin{array}{l}\text { Meningkatnya keberadaan produk-produk negara-negara } \\
\text { MERCOSUR di Indonesia }\end{array}$ & 2 & 0.14 & 0.28 \\
\hline
\end{tabular}




\begin{tabular}{ccccc}
\hline No & Faktor Eksternal & Rating & Bobot & Skor Bobot \\
\hline & Total Ancaman & & 1.11 \\
\hline Total Faktor Eksternal & & 1,00 & 2.47 \\
\hline
\end{tabular}

Sumber: Hasil Analisis (2019)

\section{Faktor Peluang}

Stabilitas ekonomi, sosial, dan politik di negara-negara MERCOSUR memiliki bobot 0,67 skor ini menunjukkan bahwa faktor ini memiliki dampak yang sangat penting terhadap pengembangan kerjasama perdagangan Indonesia-MERCOSUR jika dibandingkan dengan faktor peluang lain yang dimiliki Indonesia. Sedangkan nilai rating empat berarti kemampuan merespon peluang tersebut dalam pengembangan kerjasama perdagangan Indonesia-MERCOSUR sangat baik.

\section{Elemen Ancaman}

Kerjasama Negara MERCOSUR dengan negara lain dalam berbagai bidang menjadi ancaman atau tantangan terbesar yang dimiliki oleh Indonesia dalam mengembangkan perdagangan antarnegara. Faktor ini memiliki bobot 0,24 skor ini menunjukkan bahwa faktor ini memiliki dampak yang sangat penting terhadap pengembangan kerjasama perdagangan Indonesia-MERCOSUR jika dibandingkan dengan faktor ancaman lain yang dihadapi di Indonesia. Sedangkan nilai rating satu berarti faktor ancaman tersebut kuat pengaruhnya terhadap pengembangan kerjasama perdagangan Indonesia-MERCOSUR.

\section{c. Analisis Matriks Internal dan Eksternal (Matriks IE)}

Hasil yang diperoleh dari matriks IFE dan matriks EFE, maka dapat disusun selanjutnya dalam matriks Internal-Eksternal. Analisis Matriks IE ini digunakan untuk mengetahui posisi pengembangan kerjasama perdagangan Indonesia-MERCOSUR.

Matriks IE didasarkan pada nilai tertimbang yang diperoleh pada matriks EFE dan IFE. Nilai tertimbang IFE sebesar 2,20 yang menggambarkan kerjasama perdagangan Indonesia-MERCOSUR berada pada kondisi internal rata-rata, tidak terlalu kuat dan tidah terlalu lemah. Nilai tertimbang EFE sebesar 2,47 menggambarkan respon yang diberikan dalam pengembangan kerjasama perdagangan Indonesia-MERCOSUR kepada lingkungan eksternalnya tergolong sedang dalam memanfaatkan peluang dan mengatasi ancaman. Matriks IE dalam pengembangan kerjasama perdagangan Indonesia-MERCOSUR dapat terlihat pada Gambar 2.

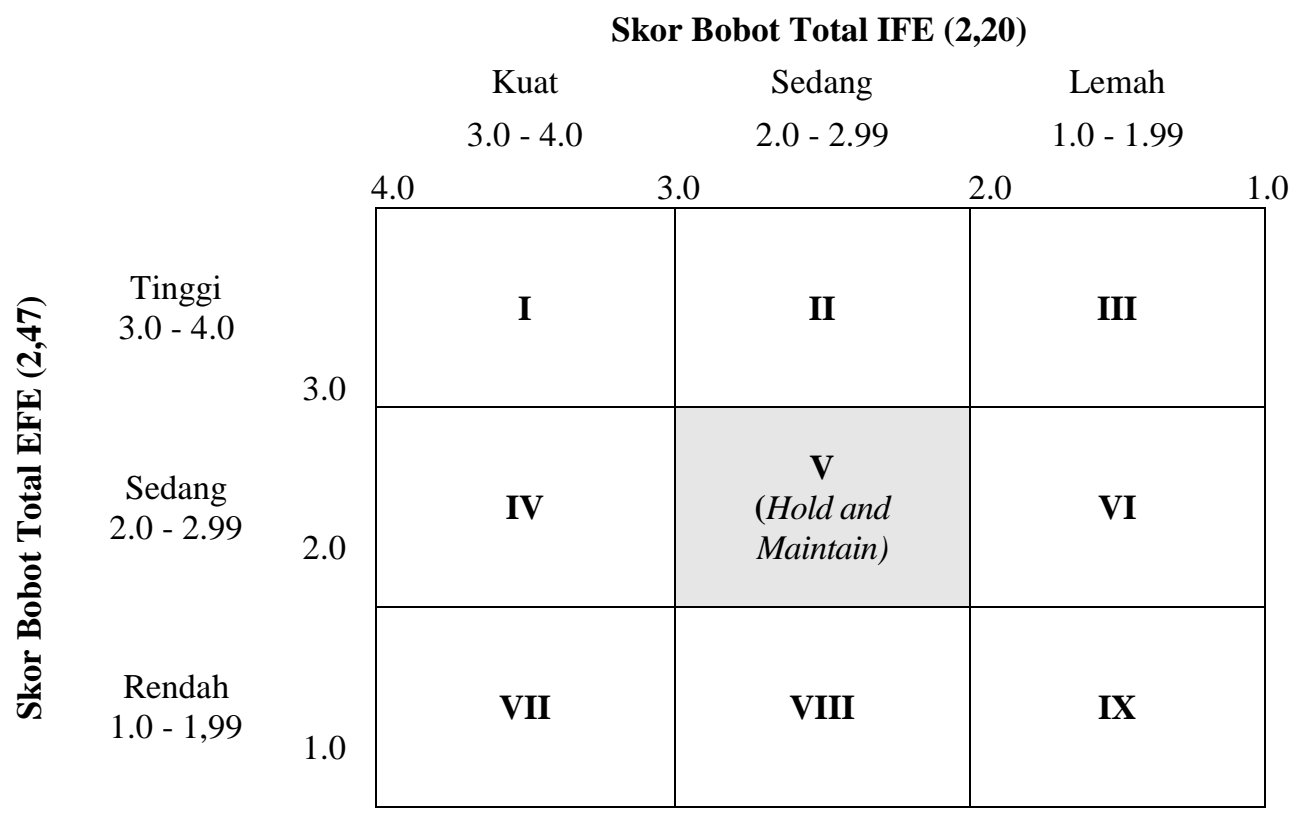

Gambar 2. Matriks IE Pengembangan Kerjasama Indonesia dengan Negara-Negara MERCOSUR 
Berdasarkan Gambar 2 posisi pengembangan kerjasama perdagangan Indonesia-MERCOSUR berada pada sel V (Hold and Maintain), sehingga strategi yang sebaiknya diterapkan pada posisi ini adalah strategi penetrasi pasar, pengembangan produk dan pengembangan pasar. Penetrasi pasar yaitu mencari pangsa pasar yang lebih besar dari produk yang sudah ada sekarang melalui perdagangan produk dan jasa Indonesia ke negara-negara MERCOSUR. Pengembangan produk yaitu mencoba meningkatkan penjualan dengan memperbaiki produk yang sudah ada atau mengembangkan yang baru untuk meningkatkan kerjasama perdagangan Indonesia-MERCOSUR.
Pengembangan pasar juga dilakukan dalam upaya mengembangakan pasar ke masing-masing negara-negara MERCOSUR. Saat ini pangsa pasar terbesar ke Brazil, dapat diperluas pasarnya ke Argentina, Paraguay maupun Uruguay.

\section{d. Analisis Matriks SWOT}

Berdasarkan analisis lingkungan internal dan eksternal dan analisis matriks IE maka dapat diformulasikan alternatif strategi yang dapat dilaksanakan dalam mengembangkan kerjasama perdagangan Indonesia-MERCOSUR. Berikut ini dijabarkan matriks SWOT.

Tabel 12. Matrik SWOT Pengembangan Kerjasama Indonesia-MERCOSUR

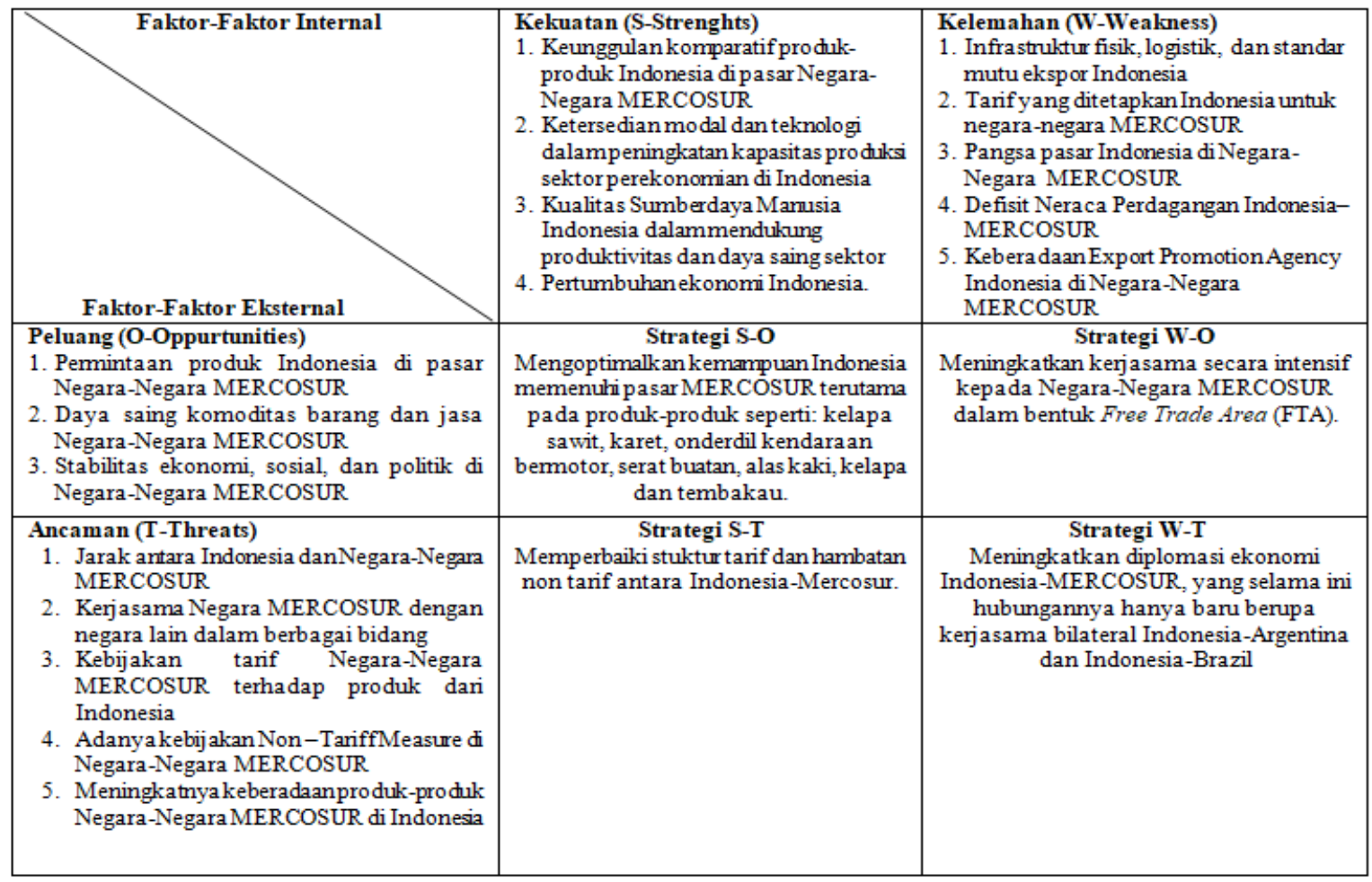

\section{KESIMPULAN DAN SARAN}

\section{Kesimpulan}

1. Berdasarkan hasil analisis, kinerja perdagangan kinerja perdagangan IndonesiaMERCOSUR, menunjukkan bahwa nilai ekspor impor Indonesia dengan MERCOSUR masih kecil dibandingkan dengan negaranegara pesaing. Produk Ekspor utama Indonesia ke MERCOSUR didominasi oleh produk kelapa sawit, karet, onderdil kendaraan bermotor, serat buatan, alas kaki, kelapa dan tembakau. Tarif impor yang diberlakukan oleh negara-negara Mercosur terhadap produk-produk utama Indonesia masih relatif tinggi, sebaliknya tarif impor yang diberlakukan oleh Indonesia terhadap produk-produk utama Mercosur relatif rendah.

2. Hasil estimasi menggunakan Gravity Model menunjukkan bahwa ekspor Indonesia ke MERCOSUR dengan GDP negara-negara MERCOSUR, GDP Indonesia, dan jarak ekonomi memiliki hubungan positif. Hanya 
GDP negara-negara MERCOSUR (tujuan ekspor Indonesia) yang bernilai signifikan.

3. Berdasarkan hasil analisis faktor internal dan eksternal, diperoleh bahwa kekuatan utama yaitu: keunggulan komparatif produk-produk indonesia di pasar negara-negara MERCOSUR. Kelemahan utama berupa: defisit neraca perdagangan IndonesiaMERCOSUR. Peluang utama, yaitu: Stabilitas ekonomi, sosial, dan politik di Negara-Negara Mercosur, dan Ancaman utama yaitu: Kerjasama Negara MERCOSUR dengan negara lain. Berdasarkan perhitungan Matriks IE dan analisis SWOT, rekomendasi strategi kerjasama perdagangan yang dihasilkan strategi penetrasi pasar, pengembangan produk dan pengembangan pasar. Berdasarkan hal tersebut, maka strategi pengembangan kerjasama perdagangan Indonesia-MERCOSUR, yaitu:

a. Mengoptimalkan kemampuan Indonesia memenuhi pasar MERCOSUR terutama pada produk-produk seperti: kelapa sawit, karet, onderdil kendaraan bermotor, serat buatan, alas kaki, kelapa dan tembakau.

b. Meningkatkan kerjasama secara intensif kepada Negara-Negara MERCOSUR dalam bentuk Free Trade Area (FTA).

c. Memperbaiki stuktur tarif dan hambatan non tarif antara Indonesia- MERCOSUR. Hal ini dapat dilakukan dengan meningkatkan kerjasama perdagangan dalam bentuk Free Trade Area (FTA).

d. Meningkatkan diplomasi ekonomi Indonesia-MERCOSUR, yang selama ini hubungannya hanya baru berupa kerjasama bilateral Indonesia-Argentina dan Indonesia-Brazil.

\section{Saran}

Peningkatan kerjasama perdagangn IndonesiaMERCOSUR diperlukan untuk menurunkan hambatan tarif dan non tarif antara Indonesia dengan Negara-Negara MERCOSUR sehingga daya saing produk-produk Indonesia meningkat di pasar MERCOSUR. Potensi peningkatan nilai ekspor Indonesia ke MERCOSUR lebih tinggi daripada potensi peningkatan impor dari Mercosur, dan mengingat struktur ekspor impor antara Indonesia dan MERCOSUR relatif sama, kerjasama perdagangan yang direkomendasikan adalah FreeTrade Agreement (FTA).

\section{DAFTAR PUSTAKA}

Amalina AAF, Tanti N, dan Alla Asmara. 2018. Analisis Kinerja Perdagangan Indonesia ke Negara Potensial Benua Afrika. Jurnal Ekonomi dan Kebijakan Pembangunan, Departemen Ilmu Ekonomi. Fakultas Ekonomi dan Manajemen, Institut Pertanian Bogor. Vol 7 No 1 (43-59).

Badan Pengkajian dan Pengembangan Kebijakan Perdagangan Kementerian Perdagangan 2015. Laporan Akhir. Analisis Potensi Perdagangan Indonesia di Kawasan Timur Tengah dan Afrika. BPPKP Kementerian Perdagangan.

Bergstrand J. 1985. Gravity Equation and Economic Friction in World Economic. United Nation.

Eita JH, Jordan AT. 2007. South Africa Export of Metal and Article of Base metal: Gravity model Approach. Journal for studies in Economics and Econometrics 31(3): $81-96$

David, R. F. 2004. Manajemen Strategi: KonsepKonsep. Edisi Ketujuh. Indeks. Jakarta.

Dilanchiev A. 2012. Empirical Analysis of Georgian Trade Pattern: Gravity Model. Journal Social Science 1(1): 75-78

Rangkuti, Freddy. 2005. analisis SWOT Teknik Membedah Kasus Bisnis.PT. Gramedia Pustaka Utama: Jakarta.

Hanoum, F N dan Mulatsih, S. 2016. Analisis Kinerja Ekspor Elektronika Indonesia ke Amerika Latin. Jurnal Ekonomi dan Kebijakan Pembangunan, hlm. 90-102. Vol 5 No 1. [ITC] International Trade Center.http://www.trademap.org/Bilatera 1_TS.aspx [28 Agustus 2019] 
Krugman P.R., Obstfeld, M. 2009. International Economics: Theory \& Policy. Clinton D, editor. Boston (US): The Addison-Wesley. Ed ke-8.

Lawless M dan Whelan K. 2007. A Note on Trade Costs and Distance. Working Paper Series, UCD Centre for Economic Research.

Marina dan Mulatsih, 2016. Analisis Kinerja Ekspor Kertas Indonesia ke Amerika Latin. Jurnal Ekonomi dan Kebijakan Pembangunan, hlm. hlm. 87-104. Vol 5 No 2.

Wardani, M A, Mulatsih S. 2017. Analisis Daya Saing dan Faktor-Faktor yang Memengaruhi Ekspor Ban Indonesia ke
Kawasan Amerika Latin. Jurnal Ekonomi dan Kebijakan Pembangunan, Departemen Ilmu Ekonomi. Fakultas Ekonomi dan Manajemen, Institut Pertanian Bogor. Vol. 6 No. 1 (81-100)

Oktaviani, R dan Tanti N (2014). Kebijakan Perdagangan Internasional (Aplikasinya di Indonesia). IPB Pers.

Salvatore D. 1997. Ekonomi internasional Jilid I. Edisi kelima. Munandar H, penerjemah; Sumiharti Y, editor. Jakarta (ID): Erlangga. Terjemahan dari: Internasional Economics. 